\title{
OS MANUAIS DE CATECISMO NAS TRILHAS DA EDUCAÇÃO: NOTAS DE HISTÓRIA
}

\author{
Evelyn de Almeida Orlando \\ Pontifícia Universidade Católica do Paraná, Brasil.
}

Resumo

Este artigo apresenta, numa perspectiva histórica, os manuais de catecismo como uma classe de impressos largamente utilizada pela lgreja em suas práticas educativas, com enfoque na sociedade brasileira. Metodologicamente o texto analisa esses livros como objetos culturais que passaram por diferentes estratégias de produção, apropriação e circulação a fim de propagar a doutrina católica de forma mais eficaz e duradoura. Indica ainda, diferentes produções materiais e discursivas que esse instrumento pedagógico adquiriu na primeira metade do século 20 . Tenha sido na catequese paroquial ou escolar, nesta última, sobretudo, os catecismos católicos contribuíram para a conformação do campo doutrinário da pedagogia católica e passaram de aparato religioso a objeto da cultura escolar.

Palavras-chave: catecismos, impressos, modernidade, história da educação.

\section{THE CATECHISM MANUALS ON THE TRACKS OF EDUCATION: NOTES FROM HISTORY}

\begin{abstract}
This article presents, in a historical perspective, catechism manuals as a class of printings extensively used by Catholic Church in its educational practices, focusing on Brazilian society. Methodologically the paper analyzes these books as cultural objects that have gone through different production, appropriation and circulation strategies in order to propagate Catholic doctrine in a more effective and permanent way. Also indicates different material and discursive aspects this pedagogical instrument acquired in the first half of the $20^{\text {th }}$ century. Whether in school or parish catechesis, the first one above all, Catholic catechisms contributed to the shaping of the doctrinal field of Catholic pedagogy and from religious apparatus turned into object of the school culture. Key-words: catechisms, printed papers, modernity, history of education.
\end{abstract}




\section{LOS MANUALES DEL CATECISMO EN LOS SENDEROS DE LA EDUCACION: APUNTES DE HISTORIA}

Resumen

Este artículo presenta, desde una perspectiva histórica, a los manuales del catecismo como un tipo de publicaciones ampliamente utilizada por la Iglesia en sus prácticas educativas, centrándose en la sociedad brasileña. Metodológicamente el texto analiza estos libros como objetos culturales que pasaron por diferentes estrategias de producción, consignación y distribución con el fin de difundir la doctrina católica de forma más eficaz y duradera. También muestra varias producciones materiales y discursivas que dicho instrumento pedagógico adquirió en la primera mitad del siglo 20. En la catequesis parroquial y sobre todo en la escolar los catecismos católicos contribuyeron a la conformación del adoctrinamiento en la pedagogía católica y pasaron de ser un instrumento religioso a un objeto de la cultura escolar. Palabras-clave: catecismos, impresos, modernidad, historia da educación.

\section{LES MANUELS DE CATÉCHISME SUR LES CHEMINS DE L'ÉDUCATION: NOTES D'HISTOIRE}

\section{Résume}

Cet article présente, d'un point de vue historique, les manuels du catéchisme comme une classe d'imprimés largement utilisée par l'église dans ces pratique éducatives, en se focalisant sur la société brésilienne. Méthodologiquement le texte analyse ces livrés comme des objets culturels qui passèrent par différentes stratégies de production, d'appropriation et de circulation à fin de propager la doctrine catholique de manière plus efficace et pérenne. Le texte indique aussi différentes productions matérielles et discursives que cet instrument pédagogique acquit dans la première moitié du $20^{\text {ème }}$ siècle. Que ce soit dans la catéchèse paroissiale ou scolaire, dans cette dernière en particulier, les catéchismes catholiques contribuèrent à la formation du champs doctrinaire de la pédagogie catholique et passèrent d'apparat religieux à objet de culture scolaire. Mots-clé: catéchisme, imprimés, modernité, histoire de l'éducation. 


\section{Introdução}

$\mathrm{N}$ a escrita da história da educação brasileira os impressos têm contribuído de forma importante. Neste artigo, a atenção se volta para uma classe específica de impressos: os catecismos católicos, impressos de destinação pedagógica para a propagação e conservação da fé e da doutrina da lgreja, que proliferaram a partir do movimento reformista e exerceram influência significativa nas práticas educativas da sociedade brasileira. A partir da análise da coleção de catecismos do monsenhor Álvaro Negromonte ${ }^{1}$, este trabalho pretende sinalizar para diferentes produções materiais e discursivas que esse instrumento pedagógico adquiriu na primeira metade do século 20 , tendo a sociedade brasileira como lócus privilegiado da análise.

As tensões, conflitos, disputas pelo campo religioso suscitaram uma série de iniciativas, como a proliferação de manuais de catecismos, as quais contribuíram para o desenvolvimento da educação no país, possibilitaram a circulação de idéias religiosas e estimularam a leitura e a escrita de diferentes grupos sociais. No Brasil, os manuais de catecismo raramente constituem objeto de estudo específico da História da Educação, do livro ou dos impressos e aparecem, geralmente, como referência de apoio a estudos sobre aspectos do ensino religioso e das práticas escolares ${ }^{2}$.

A construção dessa história segue, portanto, os fios e os rastros deixados em outras áreas, como a Teologia e a Linguística, assim como em outros campos de atuação da História, como a história do livro e da leitura, a história da igreja, a história do ensino e a própria história da educação, que configura os manuais de catecismos como objetos de formas e sentidos próprios.

\section{Entre as formas e os sentidos}

O catecismo é analisado neste trabalho como um livro de doutrina, uma publicação que tinha por finalidade a instrução, a inculcação de hábitos e valores religiosos e morais, a modelação de comportamentos, a formação do cristão. Na condição de impresso, devese considerar as suas dimensões materiais de forma articulada às suas produções de sentido. Os dispositivos materiais podem indicar, tanto a imposição de um sentido ao texto, quanto os usos que podem ser investidos aos mesmos e às apropriações às quais são suscetíveis. Pensar nesses aspectos pode aumentar as possibilidades de se decifrar a ordem que os livros procuram estabelecer (Chartier, 1996).

A história do livro aponta a tipografia como prática que começou a ser exercida desde o século 15 por impressores cristãos. Segundo Assis (2004), tal fato impulsionou o uso do catecismo como instrumento pedagógico a partir do século 16. Desde a invenção da imprensa, a Igreja Católica, experiente em copiar e manipular livros, manteve uma política determinada com relação aos impressos, os quais eram utilizados para propagar

\footnotetext{
${ }^{1}$ Intelectual e pedagogo católico que renovou o ensino de catecismo no Brasil entre as décadas de 1930 e 1960. Sobre seu trabalho e sua coleção de catecismos ver Orlando (2008).

2 Esse é o caso de trabalhos como A pedagogia catequética e a educação na primeira República (18891930", de Mauro Passos, Da leitura do catecismo à catequização da leitura: o catecismo como texto de leitura na escola primária no Brasil do século XIX, de Elomar Tambara, O catecismo como método de ensino de línguas, de Luiz Eduardo Meneses de Oliveira e Lêda Pires Corrêa, e A pedagogia dos catecismos protestantes no Brasil católico e Os catecismos protestantes no Brasil, de Ester Fraga VilasBôas Carvalho do Nascimento.
} 
suas posições, a partir do pressuposto de que todo o esforço em editar e fazer circular tais textos fazia parte do objetivo de construir uma civilização cristã.

A modernidade impulsionou a era dos impressos religiosos. Com maior circulação, eles se difundiram com o intuito de disseminar a fé, tanto católica, quanto protestante. Com isso, tornaram-se aliados na conformação de ambos os campos. Nessa perspectiva, não obstante, os vários impressos de cunho educacional que circularam no século 16, tais como a Bíblia, os breviários, os livros de hora, os opúsculos e folhetos de jornal, os catecismos, foram os impressos de maior relevo pela sua ampla circulação nos diferentes domínios sociais e culturais.

Como importante ferramenta da catequese, o catecismo, originário do grego katechismós, significa ensinar a palavra, instruir. Com um sentido mais amplo, a catequese é um conceito que diz respeito à ação eclesial que conduz, tanto os indivíduos, quanto as comunidades, à maturidade da fé. O catecismo, por sua vez, é um compêndio da doutrina da lgreja que expressa, de modo essencial, as verdades fundamentais da fé, necessárias à salvação. O texto de catecismo tem a função de sistematizar a ação catequética pelo ensino, adequando a metodologia utilizada à idade e às circunstâncias em que será aplicado.

Tendo em vista uma tansmissão via prática de leitura intensiva ou extensiva ${ }^{3}$, os manuais de catecismo se constituem em textos de referência, seguros e autênticos para o ensino da fé e da doutrina católica, iluminados pela tradição apostólica, pelo magistério da Igreja e pelas Sagradas Escrituras, o que para Bourdieu significa "um ponto de apoio que serve de roteiro, impedindo excentricidades e extravagâncias, que asseguram a economia da improvisação, mantendo-a dentro de limites (2005, p. 98). Organizado em formato de perguntas e respostas, uma novidade no século 16 , visava à transmitir a mensagem e ensinar pelo diálogo os valores e as normas da lgreja. A doutrina deveria ser aprendida em pormenores, com vistas a contribuir para a formação de um conjunto de valores e habitus próprios de um cristão.

Muito embora a existência de catecismos para ensinar a doutrina cristã seja anterior à modernidade, é neste período que essa classe de impressos ganhou maior impulso ${ }^{4}$. De acordo com Bollin e Gasparini (1998), o termo catecismo, utilizado para indicar o livrinho da doutrina cristã, já era usado, tanto em latim, quanto em língua vulgar, no século 14 e servia para exposição da doutrina do Cristianismo às pessoas ignorantes ou às crianças. Mas foi a partir da Reforma Protestante e dos usos que Lutero fez do impresso para propagação da fé, que a Igreja foi impulsionada a utilizar a mesma estratégia para

\footnotetext{
${ }^{3}$ As práticas de leitura têm se constituído objeto de investigação de alguns historiadores, que tem se voltado para a história do livro e da leitura, como Roger Chartier, Jean Hébrard, Alberto Manguel, dentre outros. Chartier (1996), ao tratar de uma prática de leitura intensiva e extensiva, nos revela comunidades de leitores diferenciadas não somente quanto aos usos que fazem do impresso, mas da sua intencionalidade, dos seus objetivos.

${ }^{4}$ É comum adotar o entendimento do catecismo associado ao método empregado. Todavia, este artigo atenta para o impresso, publicado em diferentes formatos e propondo metodologias de ensino que variaram ao longo do tempo e do local onde era utilizado. Dentre as propostas metodológicas adotadas pode-se destacar a narrativa histórico-bíblica, que surgiu no século 17. Há, ainda, a proposta de substituir a técnica da memorização pelo método socrático, baseado no diálogo, fruto do iluminismo católico. No século 20 verifica-se a existência de uma coleção de catecismos que propõe um método integral, com preferência pela explanação e pela verificação dos temas tratados pela associação com a vida, sempre que possível. Seja qual for o método, em diferentes momentos da história, os catecismos foram os principais instrumentos característicos da catequese moderna e da formação do homem civilizado.
} 
instrução e conformação da fé católica. Os catecismos adotaram, na modernidade, novos contornos. A catequese, que adotava um cunho apostólico, passou a ser utilizada pela Igreja sob uma nova ótica, a do ensino. Segundo Bollin e Gasparini, a catequese é vista como o "ensino da doutrina cristã, concentrada no catecismo, o livro (impresso!) que compila, de um modo simples, essencial e completo, tudo o que o fiel deve conhecer" (1998, p. 105).

Após a Reforma, os catecismos proliferaram e se tornaram o centro da ação pastoral-catequética. A inadequação da ação pastoral à época fez emergir a tônica do movimento reformista: a necessidade de instrução religiosa. Com isso surgiu uma onda de catecismos, protestantes e católicos, como o caminho para a m6aturação da fé e, conseqüentemente, salvação das almas. Mesmo dentre os protestantes, "muitas vezes ele foi mais popular do que a própria Bíblia" (Nascimento, 2006, p. 4).

A variedade de textos produziu dissonâncias nos discursos de ambos os lados, que buscavam associar religião e civilização em seus ensinamentos. Pautados, inicialmente, em uma prática de leitura denominada por Chartier (1996) como intensiva, os textos de catecismos serviram, tanto para inculcar os novos valores e preceitos propostos pelo protestantismo, quanto para instruir e conformar as verdades da lgreja Católica.

Essa conformação começava pelo próprio interior do campo religioso. A ignorância religiosa alcançava até o clero, que vivia em situações miseráveis, sem perspectiva, alimento intelectual e espiritual para fortalecer a sua própria fé. Isso resultou num movimento de reforma interna e a publicação do Catechismus ad parochos, mais conhecido como Catecismo Romano ou Tridentino, voltado para os párocos, como instrumento auxiliar da formação teológica, no que diz respeito ao que devia ser ensinado ao povo.

Os catecismos protestantes, largamente difundidos para a instrução do povo, adotaram duas vertentes mais claramente definidas: a de Lutero e a de Calvino. Os catecismos de Lutero têm caráter pastoral. Em 1529 ele publicou oito tábuas catequéticas para a família, o catecismo grande para a instrução dos pregadores e professores e o catecismo pequeno, mais simples e destinado aos párocos e pais de famílias para que o explicassem às crianças. Do ponto de vista metodológico, Lutero assumiu para 0 catecismo grande uma rigidez maior e utilizou um texto discursivo contínuo, tendo em vista o público para o qual foi destinado. Nessa mesma perspectiva, o catecismo pequeno foi escrito em formato de perguntas e respostas, mais didático para as crianças.

Já os textos de Calvino, que influenciaram os catecismos católicos, têm perspectiva doutrinal. Os catecismos de Calvino são uma espécie de sumários de Teologia, que condensam de forma ampla, ordenada e rigorosa o que deveria ser, obrigatoriamente, aprendido por crianças e adultos.

No embalo do êxito do projeto protestante de disseminar a fé e a instrução religiosa pelos impressos, sobretudo, dos textos de catecismo, os católicos também compilaram vários textos de catecismos que foram concebidos como manuais de doutrina cristã, destinado às crianças e aos fiéis que quisessem aprender sobre a doutrina da lgreja. Os principais catecismos católicos publicados na esteira do empreendimento protestante foram redigidos por três religiosos da Companhia de Jesus, que se empenharam na luta contra a disseminação do protestantismo: Pedro Canísio, Edmondo Auger e Roberto Bellarmino. As obras de Canísio são caracterizadas, sobretudo, pela Summa, modelo de 
síntese teológico-pastoral composta de duas partes: a sabedoria e os sacramentos. Tais catecismos foram os textos mais difundidos nos colégios da Companhia de Jesus e dominaram os países de língua alemã até metade do século 19.

As obras de Auger influenciaram os catecismos franceses e são marcados pela preocupação com a difusão do protestantismo: a sua organização procura responder, ponto a ponto, ao catecismo de Calvino. Apesar do grande êxito em pouco tempo, os catecismos de Auger foram suplantados pelos de Canísio, mais preocupado com a formação individual do que com a contestação. Ambos os autores escreveram suas obras no decorrer do Concílio de Trento. As obras de Bellarmino ${ }^{5}$, escritas depois do Concílio, alcançaram a aprovação do papa e tornaram-se obrigatórias em Roma. Foram apresentadas durante o Concílio Vaticano I como o modelo mais autorizado para a compilação do catecismo universal. Foi o texto oficioso da Igreja e o mais utilizado nas aulas de catecismos paroquiais até o compêndio de Pio X, em 1905 (Bollin; Gasparini, 1998).

O catecismo, como objeto material que veicula a relação pedagógica professoraluno, alterou as práticas catequéticas ao longo do tempo. A relação, antes fundamentada na pessoa do catequista, fundamental para transmitir a mensagem, foi transferida para o texto, para a palavra impressa. Na catequese moderna, o papel do catequista era o de explicar o livro. Naquele momento, nas aulas de catecismo, "o protagonista fundamental é o livro" (Bollin; Gasparini, 1998, p. 118).

Por mais que a Igreja Católica contestasse o processo de individualização próprio da modernidade, este se fez sentir nas aulas de catecismo. O conceito que se tinha de uma catequese apostólica na Idade Antiga e Média, baseada na oralidade, o que presumia uma interação maior entre as pessoas e uma prática de leitura socializada, foi substituído por um novo código comportamental que levava o indivíduo a uma prática de leitura individualizada, instaurado pela cultura impressa, da qual a Igreja Católica também foi partícipe:

De agora em diante a doutrina já não é apenas explicada e depois resumida em algumas fórmulas de fácil retenção. Ela deve ser apreendida em pormenor e recitada de cor. O livro já não é apenas o manual do pároco ou da pessoa instruída, que serve de guia para a instrução das pessoas. Ele é colocado diretamente na mão das crianças e dos adultos. O seu formato é tanto mais reduzido quanto mais o livro é difundido. Tudo isso é novo em relação ao passado. (Bollin; Gasparini, 1998, p. 117)

Na Europa do século 17, a multiplicação de manuais de catecismo e de instrução catequética tiveram o objetivo não só de transmitir, como assentar o espírito cristão. A disseminação das escolas religiosas tratou de formar e exibir a religiosidade dos seus membros. A ação dos colégios concorreu para transformar o século 17 num século de disputas e polarizações que ditou como norma a demonstração da fé pelo comportamento

\footnotetext{
${ }^{5}$ Os escritos catequéticos de Bellarmino se resumem em dois: a Dottrina cristiana breve perché si possa imparare a mente (1597), escrita para as crianças em forma de diálogo, em que o mestre pergunta e o discípulo responde, com 96 perguntas e respostas, e a Dichiarazione piu copiosa della Dottrina Cristiana per uso di quelli Che l'insegnano ai fanciulli e altre persone simplici, composta in forma de dialogo (1598), uma espécie de guia de orientação para sacerdotes, catequistas e professores, no qual o diálogo é invertido e o discípulo é quem pergunta e o mestre responde, com 273 perguntas-respostas (Bollin; Gasparini, 1998, p. 115).
} 
e pela conduta moral: "a religiosidade também devia ser demonstrada pelo viver cristão em sociedade, e a expressão honnête homme designava o tipo humano que demonstava cotidianamente as suas crenças, pois fora formado para isso, nas qualidades cristãs (espirituais) e sociais (cortesãs) pelos colégios" (Hilsdorf, 2006, p. 76).

A sociedade de corte, que se configurou instância social, política e econômica, determinava os novos modelos e códigos comportamentais do mundo civilizado. No século 18, a mobilidade social dos clérigos permitiu que se tornassem os principais divulgadores dos costumes da corte, que em muitos aspectos era consoante com os interesses da Igreja. $O$ controle das emoções e a formação disciplinada do comportamento, por exemplo, apresentavam afinidades com tendências particulares no comportamento eclesiástico tradicional: "civilidade ganha novo alicerce religioso e cristão" (Elias, 1990, p. 111). Isso tornou a Igreja Católica uma das mais importantes instituições de difusão dos comportamentos e estilos a partir dos estratos mais baixos da sociedade. Segundo o padre La Salle, nas suas Normas de civilidade,

a maioria dos cristãos considera o decoro e a civilidade como uma qualidade puramente humana e mundana e, não pensando em elevar mais ainda sua mente, não a considere uma atitude relacionada a Deus, ao próximo e a nós mesmos. Isto mostra bem quão pouco Cristianismo há no mundo. (apud Elias, 1990, p. 111)

O movimento cultural do lluminismo e o culto à instrução e ao esclarecimento para formar o cidadão resultou numa proposta de secularização entre Estado e Igreja, sobretudo na França, que impôs ao ensino religioso uma nova missão: criar um elo de ligação entre a Igreja e o mundo civilizado, estabelecer uma relação entre razão e fé, entre tradição e o progresso. A partir dessas iniciativas, a partir do século 18, "delineia-se uma nova pastoral que coloca a paróquia como centro do apostolado, procura afirmar a escola católica e utiliza a imprensa como apoio e sustento para a pregação" (Assis, 2004, p. 54).

Diante da proliferação de impressos de cunho educativo, como os vários tipos de textos literários que surgiram século 18, a Igreja adotou a estratégia de transformar o catecismo em disciplina escolar e assegurar a sua função formativa. A catequese e os catecismos passaram a ocupar os espaços escolares pertencentes Igreja. Os textos de catecismo, adaptados ao âmbito escolar, serviam também como manuais de primeira leitura. Neste caso, se é "impossível reconstruir uma história da cultura escrita sem encarar as modalidades da sua escolarização", tal como afirma Hèbrard (2007, p. 37), pode-se pensar nessa associação entre prática religiosa e processos de alfabetização, tal como propõe Oliveira e Corrêa:

a estreita relação entre o processo de escolarização e a cultura escrita possibilita compreender ao menos uma das razões que leva à necessidade de ancorar a formação cristã na alfabetização, que por seu turno, encadeia a aprendizagem da leitura e da escrita. Desse modo, o catecismo instaurase como instrumento capaz de interligar os domínios da fé pela alfabetização. (2007, p. 2)

Com base nessa prerrogativa, os autores defendem o catecismo como método de ensino e aprendizagem, pelo qual se entrecruzam formação religiosa e ensino de língua. 
Destacam, nesse sentido, o compêndio Breve instrucçam para ensignar a doutrina christã, ler e escrever aos meninos e ao mesmo tempo os princípios da língua portuguesa e sua orthografia, utilizado como cartilha para o ensino da língua no Estado de Pernambuco, por volta de 1759. Pensar no catecismo como método requer a atenção sobre a variação das formas, discursos e métodos pelos quais esses textos passaram ao longo do tempo.

Dos colégios jesuítas às escolas de doutrina cristã, o catecismo foi uma figura central. A partir do século 18 o seu uso, nas escolas públicas, foi discutido e adotado como uma herança do iluminismo católico ${ }^{6}$. A idéia da escola como locus ideal para a formação do homem civilizado, fruto da mentalidade lluminista, encontrou eco também no catolicismo. Segundo Nascimento,

o discurso civilizador valorizava a escola como sendo a agência destinada por excelência ao cultivo das grandes virtudes, ao fortalecimento dos espíritos, à formação do homem do futuro, o homem consciente. O homem civilizado, escolarizado, seria capaz de organizar a família em bases sólidas, simpáticas e justas, de acordo com as aspirações do progresso, em consonância com as normas científicas. (2001, p. 16)

Portanto, "a catequese escolar ou a escolarização da catequese é, de fato, uma conseqüência da mentalidade iluminista" (Bollin; Gasparini, 1998, p. 155). Se, por um lado, o iluminismo francês incitou um projeto de descristianização da nação francesa, por outro, o iluminismo alemão adquiriu contornos próprios, marca da configuração ${ }^{7}$ social que o empreendeu e fez com que se abrissem espaços nas escolas públicas alemãs e austríacas para a catequese escolar.

Catecismo e História Sacra tornaram-se disciplinas escolares e o livro de catecismo passou a ser pensado para a escola, prática que se estendeu pelo século 19. A articulação do catecismo à escola pública abriu espaço para que os padres e intelectuais católicos o associassem a qualquer outro objeto da cultura escolar, inserindo-o, portanto, nas preocupações educacionais que afloraram com a pedagogia moderna ${ }^{8}$.

A produção de catecismos no século 19, debatida durante o Concílio Vaticano I, trouxe as marcas dos novos tempos, que pediam novos objetos, novas práticas, novas representações próprias do tempo e do lugar no qual estavam circunscritas. No âmbito da catequese católica, os textos de catecismos trouxeram as marcas de duas correntes

${ }^{6}$ O iluminismo católico "não aceita as instâncias laicistas do iluminismo e quer ser um movimento de regeneração religiosa, pastoral, social, teológica, que procura o que há na fé de substancial, razoável, justo e útil. Caracteriza-se pela luta contra o fixismo doutrinal e a escolástica; pelo amplo espaço concedido à razão relativamente à fé e à autoridade; pela menor atenção prestada aos mistérios e aos novíssimos; pela preferência dada á vida moral, relativamente ao culto; pela sobriedade da oração e do culto; pela visão histórica da fé e do dogma extraídos da Bíblia. Vê no eclesiástico sobretudo um educador do povo de Deus, um mestre de moral." (Bollin; Gasparini, 1998, p. 153)

${ }^{7} \mathrm{O}$ conceito de configuração ou figuração é entendido neste trabalho tal como propõe Norbert Elias, "uma formação social, cujas dimensões podem ser muito variáveis (os jogadores de um carteado, a sociedade de um café, uma classe escolar, uma aldeia, uma cidade, uma nação), em que os indivíduos estão ligados uns aos outros por um modo específico de dependências recíprocas e cuja reprodução supõe um equilíbrio móvel das tensões" (2001, p.13).

${ }^{8}$ Essa articulação traz ainda à tona vestígios de uma circularidade cultural entre Brasil e Alemanha que se revelam na configuração de um conjunto de práticas educativas, neste caso, especificamente, católicas. Sobre essa relação Brasil-Alemanha, é interessante consultar os trabalhos de Lúcio Kreutz (1991) e Jorge Carvalho do Nascimento (1999) como importantes referências para o aprofundamento da temática.
Hist. Educ. [Online]
Porto Alegre
v. 17
ก. 41
Set./dez. 2013
p. $159-176$ 
catequéticas principais: a histórico-teológica, de tendência inovadora, e a tradicionaldoutrinal.

Em vários países, como França, Itália e Alemanha, foram adotados textos de catecismos considerados únicos em cada país. A idéia de um texto único de catecismo, considerando que o ensino da religião esteve associado ao discurso civilizador, permite inferir que se pretendia, pela religião e pelo impresso, moldar a cultura de uma nação como padrão civilizatório.

Em nome dessa civilização, no início do século 20, o papa Pio X publicou a encíclica Acerbo Nimis (1905), pela qual se buscava combater aquilo que a autoridade romana chamava de ignorância religiosa dos católicos e estimular a expansão da catequese de forma eficaz. A insistência do papa Pio X em nutrir o povo de alimento espiritual, irradiou uma obra que conclamou catequistas voluntários para os catecismos paroquiais e professores católicos catequistas em suas salas de aula, pelo acesso que estes tinham a um número maior de crianças de forma mais contínua. Essas duas frentes de ação da catequese contribuíram para fazer proliferar, mais uma vez, a produção de manuais de catecismo, que fora desencadeada no século 19 (Lustosa, 1977).

Tendo o campo educacional disputado com os protestantes e com os defensores do ensino laico, uma das estratégias adotada pela Igreja foi a da ampliação do número de instituições escolares católicas em todo o mundo, a fim de assegurar o número de fiéis pela formação educacional. O livro passou a ser não só um aparato religioso, mas um objeto da cultura escolar. A memória escrita é difundida pelo impresso, com vistas a perpetuar os valores, os comportamentos, os discursos que vigoraram e formaram as sociedades. Nesse sentido, "o livro carrega consigo a missão de educar, civilizar, universalizar e instruir" (Toledo, 2001, p. 2) e sua utilização como instrumento pedagógico, seja no espaço da Igreja ou da sala de aula, cumpriu o projeto de formar o caráter individual pensando na sua projeção social.

\section{Os catecismos católicos na educação brasileira}

O texto de catecismo, no Brasil, desde a Colônia, articulou a fé aos saberes elementares e se constituiu num importante recurso utilizado pela lgreja. $\mathrm{O}$ uso da catequese e dos manuais de catecismo deixa, ainda, em evidência que o projeto educacional desenvolvido nas terras brasileiras fazia parte de um movimento internacional pela conformação do campo religioso católico. Desde a chegada dos europeus, a necessidade dos jesuítas em lidar com a liberação sexual e moral dos habitantes nela residentes, levou-os a adotarem como estratégia para enfrentar a situação, a civilização dos costumes. Os padres jesuítas viram, no ensino de catecismo, a estratégia ideal que serviria como mecanismo de controle dos impulsos desenfreados que se encontravam e se misturavam entre os povos aqui existentes.

Os primeiros catecismos foram redigidos em tupi-guarani, para suprir a essa necessidade. Tendo em vista que, naquele momento, o seu maior ideal era a imposição de modos e padrões de conduta, utilizar a língua natal dos indígenas era o meio mais eficiente para que a apropriação desses ensinamentos ocorresse de forma efetiva.

No regime de padroado o ensino religioso teve passe livre para ditar os modelos que deveriam vigorar na nova sociedade, uma vez que a religião e a educação eram processos concomitantes e interdependentes. Divulgava-se não só as verdades da fé, 
mas também os modos de conduta socialmente aceitáveis, como os padrões de moralidade, numa rede de interdependência na qual não era possível dissociar o que era religioso do que era padrão de comportamento social. Nesse contexto, o ensino religioso e as sagradas lições do catecismo se inseriram no centro do currículo escolar.

O discurso catequético do século 18 associou o catecismo às aulas de doutrina cristã e à civilidade. Segundo Andrade,

era costume antigo utilizar-se o catecismo como cartilha de ensino de línguas D. Diogo Ortiz, Cathecismo pequeno da doctrina e instruiçam que os christaão ham de creer e obrar, para conseguir a benaventurança eterna [...] e a Grammática da linga portuguesa com os mandamentos da santa madre Igreja, de João de Barros [...] que como o autor explicita em Gramática da língua portuguesa, apesar de catecismo, funcionava como cartinha, pois dera nela a arte para os meninos facilmente aprenderem a ler com toda a diversidade de sílabas que a natureza de nossa linguagem padece. (1978, p.13-14)

Em Pernambuco, entre 1759 e 1760, foi publicada a Breve instrucçam para ensignar a doutrina christã, ler e escrever aos meninos e ao mesmo tempo os princípios da língua portuguesa e sua orthografia, provavelmente encomendada pelo governador. Esta cartilha-catecismo era uma espécie de breviário de boas maneiras e bons costumes, texto de aprendizado de leitura em língua portuguesa e manual das verdades cristãs (Andrade, 1978; Lustosa, 1992).

Com a expulsão dos jesuítas, promovida pelo marquês de Pombal, o catecismo oficialmente instituído foi o de Montpellier, elaborado em 1702, mas que em 1721 foi para o index por sua orientação janesenista ${ }^{9}$. No entanto, as suas traduções italianas, espanholas e portuguesas escaparam à condenação. Alguns bispos brasileiros resistiram a sua utilização, outros o adotaram e havia aqueles, como o cônego Luis Vieira da Silva, que possuíam, em sua biblioteca, o catecismo de Montpellier ao lado das obras do filósofo francês Bossuet, um dos principais representantes da ortodoxia católica na França do século 17 (Frieiro, 1981).

Nesse período, apesar da catequese nos moldes jesuíticos ter perdido o espaço privilegiado de aplicação, as idéias religiosas não foram abdicadas totalmente, já que o ideal de sociedade cristã civil ainda preenchia o espírito da sociedade brasileira. As novas escolas não se desvencilharam desse ideal e os novos padres leigos tiveram que se responsabilizar também da instrução catequética.

O regalismo do início do século 19 deu continuidade à prática educacional de associar a religião à educação, via catecismos como textos de leitura. De acordo com Tambara (2003), do conjunto de textos de leitura utilizados nas escolas primárias e secundárias do Brasil do século 19, figuram quarenta e seis catecismos, dos quais o título

\footnotetext{
9 "O jansenismo foi um movimento que surgiu no interior da Igreja, em 1638, e pregava que o homem é solicitado constantemente pela graça e pela concupsciência. Ele não pode resistir à graça interior. Portanto, se cai, significa que não recebeu a graça. O jansenismo tomou uma feição prática de perfeição e pretendia restaurar a austera disciplina primitiva. Dificultava a comunhão freqüente, insistia na justiça divina e nos seus castigos e reforçava a mentalidade de servos e não de filhos de Deus, 0 que enfraqueceu a vida cristã" (Negromonte, 1954, p. 114).
} Hist. Educ [Online] Porto Alegre v. 17

v. 17

ก. 41

Set./dez. 2013 p. $159-176$ 
mais mencionado, por suas traduções e reedições, é o Catecismo histórico ${ }^{10}$, do abade Fleury. Na seqüência, o catecismo de Montpellier e o Catecismo de doutrina cristã, elaborado pelo cônego Fernandes Pinheiro. Segundo Tambara, havia uma específica orientação de "enfatizar o processo de leitura escolar baseado nos textos de caráter religioso, como a determinação do art. 47, da Reforma Couto Ferraz, que indicava a leitura explicada dos Evangelhos e a notícia da História Sagrada" (Tambara, 2005, p. 3).

Em meados do século 19, começou um período de reforma católica. Segundo Passos,

esse período teve uma característica importante que foi a movimentação de um grupo de bispos, de várias partes do país, para o ensino da Doutrina Cristã [...], e se constituíram nos principais articuladores da confluência de idéias que foram gerando, sob a inspiração do Concílio de Trento e, posteriormente, reforçadas pelo Concílio Vaticano I, o movimento da reforma católica e do ensino de catecismo. (1998, p. 239)

Essa mudança de orientação no interior da Igreja, que passou a viver um período sob a égide do ultramontanismo e ganhou mais expressividade a partir da década de 70 do século 19, refletiu-se também nos textos de catecismo. No relatório de fornecimentos de livros às escolas do Rio Grande do Norte, segundo Tambara, constam, predominantemente, três livros religiosos que merecem destaque: Moral religiosa, de Ambrosio Rendu, História bíblica, do ex-bispo do Pará, e o Catecismo de doutrina cristã. Este último teve uma doação expressiva em relação a outros livros ofertados à escola. De acordo com Tambara (2005), o dr. Abílio Borges doou 400 exemplares dos seus livros de leitura, o dr. Macedo doou 18 exemplares do seu Corographia do Brasil, e, o então presidente da Província, João Capistrano Bandeira de Melo, juntamente com o diretor da Instrução Pública, Gomes da Silva, doaram 1.000 exemplares do Catecismo da doutrina cristã.

Nesse esforço de renovação do clero e na esteira do incentivo do governo, foram publicadas uma variedade de textos de catecismo, inspirados no catecismo romano, que se constituíram em importantes meios para reformar os princípios da fé cristã e acabaram, dessa forma, por substituir o Catecismo histórico e o Catecismo de Montepellier. Além disso, como afirma Lustosa (1992) foram publicadas cartilhas mais simples, sobretudo para servirem de auxiliares de ensino aos catequistas, muitas vezes com pouca habilitação. Essas cartilhas eram dosadas em nível de conteúdo e de acordo com as idades.

Nesse projeto, empreendido concomitantemente com a Lei Imperial de 1827, segundo Azzi (1977), o catecismo de dom Romualdo foi o primeiro texto a surgir, em 1831, e teve um papel importante como pioneiro pelo esforço que apresentou contra as idéias jansenistas no Catecismo de Montpellier. Depois seguiu, segundo Passos (1998), o Catecismo de mariana, também conhecido como Catecismo de D. Viçoso. Nessa mesma

\footnotetext{
${ }^{10}$ Esse catecismo foi publicado em 1683 e é dividido em uma introdução, o pequeno e o grande catecismo. Os dois catecismos se dividem em duas partes: uma histórica e a outra em que se trata a doutrina cristã de forma narrativa. A sua proposta era de substituir o catecismo doutrinal pelo histórico-bíblico. Seu catecismo conheceu "um notável sucesso livreiro" e abriu um caminho para a idéia da catequese associada à Bíblia. Desde então, a catequese baseada na história nunca mais se apagou no movimento catequético e se multiplicaram as publicações dos compêndios de História Sacra (Bollin; Gasparini, 1998, p. 152).
} 
linha seguiu a Cartilha católica dos principais pontos da doutrina cristã, publicada pelo bispo do Rio de Janeiro, discípulo de Dom Viçoso. Houve, também, os catecismos de dom Antônio Joaquim de Melo (1859), dom Joaquim Manuel da Silveira (1866). Em São Paulo, dom Lino Deodato Rodrigues de Carvalho fez a reimpressão do manual redigido por dom Antônio Joaquim de Melo e dom Macedo redigiu o Catecismo da igreja católica para uso do povo e o Catecismo do Pará, sendo este último de grande repercussão.

Mas não só os bispos publicaram catecismos. Leigos também se dedicaram a essa tarefa:

O Visconde de Cairu escreveu uma Cartilha da escola brasileira para a instrução na religião do Brasil, uma filha de Maria traduz do francês para a nossa língua um Manual da primeira comunhão e da confirmação, outro leigo, Joaquim Maria de Lacerda, publica a Pequena enciclopédia religiosa, contendo catecismo da doutrina cristã, resumo das provas da religião, história sagrada para uso das escolas brasileiras, e enfim, pode-se também anexar a esses esforços o do próprio Antônio Conselheiro, cujo livro de prédicas mostra como a fé se transmitia nos meios populares, sem esquecer o empenho de tantos "santos" e "beatos" desconhecidos que por vezes foram - e continuam sendo - os únicos a levar a muitos lugares dos sertões o eco (catequese) da mensagem evangélica. (Vilela, 1998, p. 304)

Apesar dos esforços envidados, no Brasil, a separação entre Estado e Igreja, que se instaurou com a República, e a consequente retirada de forma oficial do ensino religioso nas escolas, serviu como explicação para a situação de ignorância religiosa que, de acordo com D. Leme, na sua carta pastoral de 1916, era a causa de todos os males da sociedade.

Nessa luta contra a ignorância religiosa, a catequese passou a ter função primordial na doutrinação dos indivíduos. Um bom ensino de catecismo deveria assegurar a educação moral da consciência dos indivíduos (Orlando, 2008). Nessa perspectiva, era preciso nutrir o povo de instrução religiosa. Do conjunto de estratégias para reconstruir a cristandade brasileira e promover a civilização cristã, os dois eixos norteadores das práticas empreendidas estavam atrelados a duas frentes de ação: a escola e a imprensa. Uma rede de colégios confessionais católicos se alastrou, com vistas à formação de uma elite dirigente, consoante com a tradição e cultura católica. $O$ saber letrado foi a arma escolhida pela Igreja para "redefinir seu papel na sociedade republicana, recuperando e ampliando o poder que detinha desde os tempos coloniais" (Gebara, 2006, p. 90).

A imprensa católica se desenvolveu para combater as doutrinas anti-católicas e como instrumento de destinação pedagógica. Os vários usos atribuídos à imprensa deram-se, sobretudo, pelo fato dos espaços escolares serem voltados a uma elite mais restrita. As bibliotecas pedagógicas católicas, objeto de estudo de Donizetti Sgarbi (2001), corroboram com esse princípio. Elas encerravam as produções do Centro D. Vital e da Confederação Católica Brasileira de Educação nos periódicos $A$ Ordem e Revista Brasileira de Pedagogia, que tinham por objetivo a conformação do campo pedagógico, como ferramentas pedagógicas utilizadas para forjar uma cultura cristã. Essa estratégia partia do entendimento católico que percebia o campo pedagógico para muito além dos muros escolares. Segundo Sgarbi, os católicos "acreditavam que, por meio do livro e de seus similares, difundido, sobretudo, entre os intelectuais, os formadores de opinião, poderia se iniciar a recristianização do Brasil" (2001, p. 9). 
No intuito de ordenar a avalanche em prol da catequese, as conferências episcopais elaboraram a Pastoral de 1915, a qual, dentre outras coisas, regulamentou o ensino do catecismo e estabeleceu um catecismo padrão, que sintetizava, em seus temas, as preocupações da Igreja à época. Esse catecismo era composto por três volumes e serviu, por algumas dezenas de anos, para a instrução religiosa primária. De acordo com Mauro Passos (1999), os três manuais foram organizados da seguinte maneira: o Catecismo resumido da doutrina cristã, o Primeiro, o Segundo catecismo e o Terceiro catecismo e foram publicados pela editora Vozes. Posteriormente, o catecismo resumido foi incorporado ao segundo catecismo, correspondendo a três níveis diferentes que, posteriormente, foram reagrupados em Catecismos Menores, referentes aos dois primeiros catecismos, e Catecismo Maior, referente ao último. No entanto, segundo Lustosa,

o primarismo dos métodos empregados, a tendência de uma catequese que se esgotava e fechava com a primeira comunhão, a generalização da idéia de um catecismo desligado da vida não apresentariam os remédios necessários à correção dos males profundos da ignorância religiosa. Além do mais, era uma catequese feita predominantemente com um espírito preventivo contra o espiritismo e o protestantismo. (1977, p. 52)

A dureza dos textos e o desinteresse que eles causavam nos alunos levaram muitos padres e leigos a repensarem os materiais utilizados no ensino de catecismo. $O$ movimento catequético de Munique inspira os debates acerca da renovação de catecismo e, no Brasil, destaca-se o padre Álvaro Negromonte, um dos seus principais divulgadores.

As contribuições das correntes internacionais para a reformulação do ensino religioso foram levadas à discussão no Primeiro Congresso Catequético Brasileiro, realizado em Belo Horizonte, em 1928. A partir daí, desencadeou-se uma série de discussões que permitiu pensar em uma renovação da pedagogia catequética, com abertura para novos temas, novas abordagens, outras direções sobre as questões de ordem metodológica e didática, avaliação de manuais utilizados nas aulas de catecismo e a formação das catequistas. Nesse evento são mencionados também os congressos catequéticos europeus e, de acordo com Mauro Passos (2008), a relevância do congresso estava, sobretudo, relacionada à abertura para o debate sobre a pedagogia catequética com outros atores envolvidos com a temática do catecismo, o que trouxe à tona "uma série de subsídios para estudo que ainda estavam na sombra do movimento catequético" (Passos, 2008, p. 449). Nesta perspectiva, este congresso é apontado por Passos como "um ensaio de mudanças, tendo suas conclusões sido sentidas nas décadas seguintes, com o impulso particular do padre Negromonte, que se esforçou para sistematizar e ampliar o significado da catequese" (p. 454).

Em meados dos anos de 1930, inserido no movimento internacional com o qual já mostrava um diálogo desde finais dos anos 1920, Negromonte passou a adotar as estratégias empreendidas por seus colegas em diferentes países, como a organização de congressos para debater as questões da catequese, organização de semanas catequísticas, publicação de revistas e livros pedagógicos, com vistas a atingir um público maior e propiciar uma formação católica mais sólida. Passo a passo, ele ocupou o cenário educacional por diferentes caminhos, dentre eles, o da escolarização da catequese. 
Sob esse influxo, publicou uma coleção de manuais de catecismos didáticos, composta por quatorze livros, destinada da $1^{\text {a }}$ série ao curso normal. Inicialmente, foram escritos como livros individuais de doutrina e moral, destinados aos alunos do secundário ou de cursos de religião. Posteriormente o projeto foi ampliado e constituiu uma coleção destinada a todas as séries escolares, sem descartar os possíveis usos nas aulas de catecismo paroquiais. A ampliação do alcance da catequese de forma mais atrativa estava em consonância com os discursos produzidos pelas ciências da educação e se refletia nos livros, os quais mostravam uma preocupação maior com o seu destinatário: formato, que variava nas cores e nas ilustrações; brochura, para facilitar o manuseio; conteúdo, adaptado às diferentes idades.

A principal estratégia de ação de Negromonte foi propor uma reformulação nos textos de catecismo em um duplo aspecto: material e textual. O novo significado da catequese compreendia uma formação voltada para a vida religiosa na prática. Deveria se ensinar a doutrina sem perder de vista o aspecto formativo da educação religiosa, mas de forma atraente, interessante e eficaz para o objetivo ao qual se propunha. Os antigos manuais não atendiam a essas expectativas. Faziam-se necessários novos textos:

Os novos textos, se quiserem realmente servir à finalidade do catecismo, que é formar o cristão prático, devem ter uma feição inteiramente diversa da atual. Sei que diante de um catecismo novo, todos sentiremos uma impressão estranha. Temos na mente aquelas perguntas, aquelas expressões que decoramos em criança e ensinamos mil vezes aos pequenos; acostumamo-nos aquela ordem de matéria; afizemo-nos até o tipo de livro dos nossos catecismos [...] Mude-se aquilo e nós estranharemos [...] Mas é preciso mudar! (Negromonte, 1942, p. 75)

As mudanças às quais Negromonte se referia diziam respeito à linguagem do texto, ao conteúdo, à didática, a aproximação com a realidade, ao caráter prático das lições e, por fim, ao aspecto tipográfico:

Quem conhece psicologia infantil sabe o desprestígio de um livro pequenino, tipo miúdo, sem ilustrações, em face dos livros grandes, texto claro e variado correndo entre as figuras que falam muito mais do que as letras. E quem sabe o encanto de um novo livro vê logo que entre os manuais que variam a cada ano despertando o interesse e o entusiasmo dos pequenos, o mesmo catecismo passando, velho e conhecido, de ano para ano fará bem triste figura. (Negromonte, 1942, p. 78)

Logo depois da publicação desse artigo na Revista Eclesiástica Brasileira, Negromonte lançou a série Meu catecismo, voltada para o curso primário. Além disso, ao falar da necessidade de renovação nos textos, Negromonte apontou algumas iniciativas que, segundo ele, não foram bem-sucedidas, mas não anunciou o seu projeto de forma específica, deixando apenas a necessidade e a justificativa para a publicação da série primária. Ao propor um novo texto de catecismo, Álvaro Negromonte não se referiu a uma mudança textual, de conteúdo somente. Ele foi além. Preocupado em tornar o livro um recurso eficaz para as aulas, sua atenção se voltou para os aspectos teórico, metodológico e técnico do objeto em questão: "sei que dar um texto novo de catecismo (e não um novo texto) de catecismo é tarefa dificílima. Mas é tão necessária que merece nossos melhores esforços" (lbid., p. 82). 
A preocupação do padre com a forma dos textos de catecismos reflete a aproximação deste com as idéias que circulavam em torno da renovação do campo pedagógico e da produção do livro como objeto da cultura material escolar. Na elaboração do programa de literatura infantil para a Escola de Professores do Instituto de Educação do Distrito Federal, nota-se uma preocupação com um conjunto de critérios referentes a uma boa publicação, compartilhados por outros profissionais da educação. Dentre esses critérios, praticamente normativos, figuravam a preocupação com o conteúdo do texto, a organização, a atualidade e a exatidão das noções postas, a adaptação aos interesses básicos das crianças, as qualidades artísticas, a linguagem apropriada, correta, clara e simples e os cuidados com a feição material, com o formato, a impressão, o papel e as gravuras utilizadas. Todos esses aspectos buscavam tornar mais aprazível o manual escolar e $o$ ato de ler (Vidal, 2001). Na escola moderna, a forma de tratamento do aluno, em relação ao livro, não estimulava a reverência. Ao contrário, a intimidade entre sujeito e objeto da cultura tinha em vista estreitar essa relação. Nessa concepção, "o livro deveria ser amado, conquistado pelo leitor ou leitora, transformado em objeto de trabalho. Alunos e alunas acostumavam-se ao livro" (Ibid., p. 106).

Pode-se dizer que a reformulação do ensino religioso, por meio de manuais de catecismo mais interessantes, auxiliou no projeto de recristianização da sociedade brasileira. A publicação de novos livros de catecismos, em um novo suporte material e textual, tinha um significado mais amplo para a Igreja, que ia além da esfera pedagógica e recaía no âmbito político. Publicar é tornar algo público. É fazer, conforme assinala Bourdieu, "passar do oficioso ao oficial. A publicação é a ruptura de uma censura" (2001, p. 244). Publicar novos textos de catecismos era uma demonstração pública do diálogo católico com os novos tempos.

\section{Considerações finais}

A profusão de catecismos que se desenvolveu na modernidade, os variados formatos e usos que receberam, a presença e a circulação intensa desses textos nos espaços e nas políticas públicas de educação, revelam o diálogo entre lgreja e modernidade. Constitui, ainda, uma resposta à divisão política e religiosa e à probreza cultural e pastoral em que se encontrava a Igreja Católica no contexto da modernidade.

O investimento da Igreja num impresso de destinação pedagógica como o catecismo atingiu, com êxito, pontos nevrálgicos da instituição: contribuiu para a propagação da fé católica, para a superação do estágio de ignorância religiosa em que se encontrava o povo cristão e se constituiu como instrumento eficaz para o empreendimento de um novo projeto de cristianização.

A produção de um conjunto de livros produzidos pela Igreja tinha o intuito de atingir não só o intelecto humano, mas também mover "os sentidos e o coração para o bem de modo que a inteligência ficasse voltada para Deus" (Assis, 2004, p. 93). Portadores da autoridade da Igreja e da tradição, os livros de religião, de uma maneira geral, e especificamente os livros de catecismo, exercem o que Assis diagnosticou como "uma dupla influência no homem: a de se deixar ensinar pela autoridade da Igreja e a de manter seu pensamento e sentimento voltados para o infinito" (Ibid., p. 93). Assim, tais livros fariam parte da composição conceitual de educação na perspectiva da pedagogia 
católica, a qual não compreende educação que não seja integral, voltada para a formação da mente e da alma.

Os estudos sobre essa temática, no campo da História da Educação, ainda são raros, assim como o uso desse tipo de impresso como fontes de pesquisa. Se a cultura impressa tem chamado a atenção dos historiadores da educação, por meio de livros, impressos pedagógicos e da imprensa periódica educacional, é de salutar importância considerar os manuais de catecismo como um objeto cultural que permite apreender vestígios de práticas educativas em diferentes tempos e espaços. Neste sentido, ao historiador da educação ainda fica muito a investigar sobre a produção, circulação e apropriação desse tipo de impresso, utilizado de diversas formas pelos diferentes grupos que os assumiram como manual de educação religiosa.

\section{Referências}

ANDRADE, Antônio Banha de. A reforma pombalina dos estudos secundários. São Paulo: Saraiva/USP, 1978.

ASSIS, Raquel Martins de. Psicologia, educação e reforma dos costumes: lições da Selecta Catholica (1846-1847). Belo Horizonte: UFMG, 2004. 279f. Tese (doutorado em Educação). Faculdade de Educação, Universidade Federal de Minas Gerias.

AZZI, Riolando. A catequese no Brasil: considerações históricas. Convergência, n. 10, 1977, p. 491-513.

BOLLIN, Antônio; GASPARINI, Francesco. A catequese na vida da lgreja: notas de história. São Paulo: Paulinas, 1998.

BOURDIEU, Pierre. Gênese e estrutura do campo religioso. In: BOURDIEU, Pierre. $A$ economia das trocas simbólicas. São Paulo: Perspectiva, 2005, p. 27-98.

CHARTIER, Roger. A história cultural: entre práticas e representações. Rio de Janeiro: Bertrand Brasil, 1990.

CHARTIER, Roger. A ordem dos livros: leitores, autores e bibliotecas na Europa entre os séculos XIV e XVIII. Brasília: UNB, 1994.

CHARTIER, Roger. Formas e sentidos: cultura escrita: entre distinção e apropriação. Campinas: Mercado de Letras/ALB, 2003.

CHARTIER, Roger. Práticas de leitura. São Paulo: Estação Liberdade, 1996.

ELIAS, Norbert. O processo civilizador: uma história dos costumes. Rio de Janeiro: Jorge Zahar, 1990.

ENCÍCLICA ACERBO NIMIS. Carta Encíclica de Sua Santidade o Papa Pio X sobre o Ensino de Catecismo em 15 de abril de 1905. Rio de Janeiro: Vozes, 1946.

FRIEIRO, Eduardo. O diabo na livraria do cônego: como era Gonzaga? e outros temas mineiros. São Paulo: Itatiaia/USP, 1981.

GEBARA, Ademir. Educação e civilização na província de São Paulo. In: SCOCUGLIA, Afonso Celso; MACHADO, Charliton José dos Santos. Pesquisa e historiografia da educação brasileira. Campinas: Autores Associados, 2006, p. 63-86.

GINZBURG, Carlo. O fio e os rastros: verdadeiro, falso, fictício. São Paulo: Companhia das Letras, 2007. 
HÉBRARD, Jean. Três figuras de jovens leitores: alfabetização e escolarização do ponto de vista da história cultural. Campinas: Mercado de Letras/ALB; São Paulo: Fapesp, 2000.

HILSDORF, Maria Lucia Spedo. O aparecimento da escola moderna: uma história ilustrada. Belo Horizonte: Autêntica, 2006.

KREUTZ, Lúcio. O professor paroquial, magistério e imigração alemã. Porto Alegre: Ufrgs, 1991.

LUSTOSA, F. Oscar. A presença da igreja no Brasil: história e problemas (1500-1968). São Paulo: Giro, 1977.

LUSTOSA, F. Oscar. Catequese católica no Brasil: para uma história da evangelização. São Paulo: Paulinas, 1992.

NASCIMENTO, Ester Fraga Vilas-Bôas Carvalho do. Os catecismos protestantes no Brasil (1864-1916). Revista do Mestrado em Educação. São Cristóvão: Universidade Federal de Sergipe, v. 11, 2007, p. 7-22.

NASCIMENTO, Jorge Carvalho do. A cultura ocultada ou a influência alemã na cultura brasileira durante a segunda metade do século XIX. Londrina: UEL, 1999.

NASCIMENTO, Jorge Carvalho do. Nota prévia sobre a palavra impressa no Brasil do século XIX: a biblioteca do povo e das escolas. In: Revista Horizontes. Bragança Paulista: USF, 2001, p. 11-28.

NEGROMONTE, Álvaro. História da igreja: para o curso colegial. Rio de Janeiro: José Olympio, 1954.

NEGROMONTE, Álvaro. Um texto novo de catecismo. Revista Eclesiástica Brasileira, Petrópolis: Vozes, v. 2, fasc. 1, 1942, p. 72-82.

OLIVEIRA, Luiz Eduardo Meneses; CORREAA, Lêda Pires. O catecismo como método de ensino de línguas. ENCONTRO DE PESQUISA EDUCACIONAL NORTE E NORDESTE, 18, 2007, Alagoas. Anais... Alagoas: Edufal, 2007.

ORLANDO, Evelyn de Almeida. Por uma civilização cristã: a coleção Álvaro Negromonte a pedagogia do catecismo (1935-1964). São Cristóvão: UFSE, 2008. 365f. Dissertação (mestrado em Educação). Faculdade de Educação, Universidade federal de Sergipe.

PASSOS, Mauro. A pedagogia catequética e a educação na primeira República (18891930). Roma: Universitá Pontificia Salesiana, 1998. 546f. Tese (doutorado em educação). Universitá Pontificia Salesiana.

SGARBI, Antônio Donizetti. Bibliotecas pedagógicas católicas: estratégias para construir uma civilização cristã e conformar o campo pedagógico através do impresso (1929-1938). 375f. São Paulo: PUCSP, 2001. Tese (doutorado em Educação). Faculdade de Educação, Pontifícia Universidade Católica de São Paulo.

TAMBARA, Elomar Antônio Callegaro. Bosquejo de um ostensor do repertório de textos escolares utilizados no ensino primário e secundário no século XIX no Brasil. Pelotas: Seiva, 2003.

TAMBARA, Elomar Antônio Callegaro. Da leitura do catecismo à catequização da leitura: o catecismo como texto de leitura na escola primária no Brasil do século XIX. SIMPÓSIO NACIONAL DE HISTÓRIA, 23, 2005, Londrina. Anais... Londrina: Mídia, 2005.

TOLEDO, Maria Rita de Almeida. Coleção atualidades pedagógicas: do projeto político ao editorial (1931-1981). São Paulo: PUCSP, 2011. 295f. Tese (doutorado em Educação). Faculdade de Educação, Pontifica Universidade Católica de São Paulo. 
VIDAL, Diana Gonçalves. Práticas de leitura na escola brasileira dos anos 1920 e 1930. In: FARIA Filho, Luciano Mendes. Modos de ler, formas de escrever: estudos de história da leitura e da escrita no Brasil. Belo Horizonte: Autêntica, 2001a, p. 88-116.

VILELA, Magno. A tradição da catequese no Brasil. In: BOLLIN, Antônio; GASPARINI, Francesco. A catequese na vida da Igreja: notas de história. São Paulo: Paulinas, 1998, p. 259-327.

EVELYN DE ALM EIDA ORLANDO é professora no Programa de Pós-Graduação em Educação da Pontifícia Universidade Católica do Paraná. Doutora em Educação pela Universidade do Estado do Rio de Janeiro e mestre em Educação pela Universidade Federal de Sergipe.

Endereço: Rua Nicolau Maeder, 463/208 - 80030-330 - Curitiba - PR - Brasil.

E-mail: evelynorlando@gmail.com.

Recebido em 7 de novembro de 2012.

Aceito em 3 de maio de 2013. 